Leonardo Miucci

\title{
Completing the Score. Beethoven and the Viennese Piano Concerto Tradition ${ }^{1}$
}

Some recent studies on the Viennese Classical piano concerto repertory have highlighted the necessity of properly considering historical context in order to identify performance guidelines compatible with both historically informed criteria and the apparent lack of notational information left by the composers in the authorized editions. ${ }^{2}$ In other words, these studies stress the risk of treating these scores with a historically incorrect sacredness. These contributions also devote considerable attention to improvisation and embellishment, aiming to shed further light on the treatment of both texts expressly left unfinished by the composer and points calling for improvisation (Eingänge and cadenzas).

Such studies focused particularly on Mozart's case, an understandable choice given several factors. ${ }^{3}$ First and foremost is the fact that, despite his enormous output (approximately 30 piano concertos), Mozart was involved in the publication process of only a very small number of these concertos. In the majority of circumstances (including masterpieces like KV 466, 49I, 488 et alia), these works were published posthumously in the economic interest of Mozart's wife and publishers. Therefore, for these and many other works, the editio princeps produced in the early $\mathrm{I}^{\text {th }}$ century was principally based on Mozart's manuscripts, and musicological investigations have demonstrated through scientific arguments that these posthumous editions are incomplete in several aspects, concerning both the performing indications and the musical texture. 4

1 I deeply thank Michael Ladenburger for his special support along this study and Dalyn Cook for her kind assistance with the English language.

2 See, for example, Robert D. Levin: Instrumental Ornamentation, Improvisation and Cadenzas, in: Performance Practice. Music after I6oo, ed. by Howard Mayer Brown and Stanley Sadie, New York I989, pp. 267-29I; Philip Whitmore: Unpremeditated Art. The Cadenza in the Classical Kepboard Concerto, Oxford I99I.

3 See Frederick Neumann: Ornamentation and Improvisation in Mozart, Princeton I986; Christoph Wolff: Cadenzas and Styles of Improvisation in Mozart's Piano Concertos, in: Perspectives on Mozart Performance, ed. by Larry Todd, Cambridge I99I, pp. 228-238; Robert D. Levin: Improvised Embellishments in Mozart's Keyboard Music, in: Early Music 20 (I992), pp. 22I-234; David Grayson: Whose Authenticity? Ornaments by Hummel and Cramer for Mozart's Piano Concertos, in: Mozart's Piano Concertos. Text, Context, Interpretation, ed. by Neal Zaslaw, Ann Arbor 1996, pp.37339I; Leonardo Miucci: Mozart after Mozart. Editorial Lessons in the Process of Publishing J. N. Hummel's Arrangements of Mozart's Piano Concertos, in: Music+Practice 2/I (20I4) - www. musicandpractice.org.

4 See the complex case of KV 49I, among others, in the bibliography listed in the former footnote. 
Thus, using the Urtext editions available nowadays could be dangerous if the score is decontextualized from its complex historical picture. This caveat, which still must be disseminated more widely among academic institutions and in the performance world, has been recognized in recent decades regarding Mozart's works. Although the early Beethovenian repertory was essentially coeval with the Mozartean one, it has received relatively little attention in this respect. Would it be possible to trace a sort of continuity with the approach and circumstances of his predecessor, or would Beethoven represent an evolutionary step in the history of this piano genre, breaking somehow with the former tradition? Even if the answers to such questions require the consideration of a complex constellation of factors, it is reasonable to believe, as this contribution will illustrate, that Beethoven's works in fact embody both these tendencies: conservation and evolution.

Among the profound changes that occurred in just a few decades - those exactly coincidental with Beethoven's compositional period - were sociological shifts that encouraged composers to publish more of their works. Consequently, composers were increasingly involved in the publication process, including Beethoven: excepting his works without opus, he took a very active part in the publication of all his concertos. This historical change merits deeper investigation.

The revolutions that occurred in Europe between the $18^{\text {th }}$ and $19^{\text {th }}$ centuries profoundly changed the context of the piano concerto. The political, social and industrial revolutions precipitated the rise of the middle class and added a global dimension to the world of music-making in general and to the domain of the keyboard in particular. For instance, in the late $1^{8^{\text {th }}}$ century, music performance was an activity mainly reserved for an exclusive circle of aristocrats: in I839, Henri Herz described it as "a time, not far from us, when the use of Piano-Forte was a privilege of the well-off people and the aristocrats". 5 The newly emerged middle class created not only a larger consumer market but also introduced new and increasingly active participants in music-making. This significant change was already recognized by contemporary personalities such as Anton Schindler (I795-I864), one of the most controversial Beethoven biographers; he pictures the scene thus:

"In all Germany, and particularly in Vienna, music was much cultivated, and that chiefly good music (because then there was not so much bad produced as succeeding years have brought forth); for the lower classes, among whom there had previously been many attentive auditors, began to pay more and more attention to the divine art, but at the same time rarely possessed high mental cultivation, or had a just conception of the nature of music and its sublimest object".6

5 "A une époque peu éloignée de nous, l'usage du piano était un privilège exclusif de l'opulence et l'aristocratie." Henri Herz: Méthode complète de piano, op. Ioo, Mainz I839, Préface, p. I.

6 See Anton Schindler: The life of Beethoven, London I84I, Vol. I, p. 65 f.; English translation of id.: Biographie von Ludwig van Beethoven, Münster r840. 
As a result of the influx of amateur musicians in the first decades of the $\mathrm{I}^{\text {th }}$ century, a schism between keyboard composer and performer is born, a separation that would increase through the second half of the century and would become fully institutionalized throughout the $20^{\text {th }}$ century. During Mozart's time, it was rare to attend a performance of his piano concertos where the performer was someone other than the composer himself or someone closely connected to him. There is evidence that, on occasion, his sister Nannerl or Barbara Ployer, one of his most accomplished students, performed this repertory with Mozart's blessing. Maria Anna Mozart and Ployer were close enough to Mozart that they clearly understood, or were likely instructed by the composer in, the role of the performer in such repertory, which often required an improvised contribution. In other words, they realized that the score itself was only a sketch of the concerto and that the performer was responsible for fleshing it out through his/her own musical additions. Finally, it should be noted that concertos were often composed for a specific occasion and immediately shelved thereafter to make room for a new work; the concept of a permanent repertory had not yet developed, and the allure of a piano concerto was its newness.

During the early ${ }^{\text {th }}$ century, however, this picture drastically evolved. The number of public performances constantly increased, and piano concertos - for which performance traditions had begun to develop - were performed by pianists from diverse musical backgrounds.

This crucial factor, among others, inevitably had important consequences for the composers' attitude, their usus componendi, and for the evolution of the piano concerto genre itself. The dimensions of this phenomenon become apparent through an examination of the evolution of the cadenza. Consider how Hummel describes this shift in I828:

"Die sogenannte Schlussfermate (Cadenza, Tonfall) kam früher häufig in Konzerten etc. meist gegen Ende eines Stücks vor, und der Spieler suchte in ihr seine Hauptstärke zu entwickeln. Da aber die Konzerte eine andere Gestalt erhalten haben, und die Schwierigkeiten in der Komposizion selbst vertheilt sind, so gebraucht man sie selten mehr. Kommt noch zuweilen in Sonaten oder Variazionen ein solcher Haupt-Ruhepunkt vor, so giebt der Komponist selbst dem Spieler die Verzierung an." 7

Sociological developments consistently and profoundly influenced performance practices, which in turn shaped Beethoven's compositional style, leading him to situate his music equidistantly to both $\mathrm{I} 8$ th century Classical tradition and the new demands of the I $9^{\text {th }}$ century. Thus in Beethoven's works, it is possible to find traces of both stylistic

7 See Johann Nepomuk Hummel: Ausführliche theoretisch-practische Anweisung zum Piano-Forte-Spiel, Wien [1828], p. 55 . 
conservation and evolution, tendencies which converge in the improvisational elements in his piano concertos.

This historical moment of change, which parallels the development of the cadenza as described above by Hummel, was explicated by another key figure in the piano world, Carl Czerny, who writes in I839:

"In den neueren Compositionen werden die Zeichen des Vortrags von den Autoren meistens so ausführlich angewendet, dass der Spieler im Allgemeinen selten über den Willen des Compositeurs in Zweifel sein kann.

Aber selbst da gibt es Fälle, wo vieles der Willkühr des Spielers überlassen bleibt, und in älteren Clavier-Werken, (z. B: von Mozart, Clementi, etc.) wo jene Zeichen äusserst sparsam sich angezeigt finden, hängt der Vortrag meistens von dem Geschmack und der Einsicht des Vortragenden ab. Daher ist der Vortrag dieser Werke in dieser Rücksicht weit schwerer." ${ }^{8}$

This paper aims to trace the influence of this evolving musical world on the language of Beethoven's piano concertos through an examination of improvised embellishments and cadenzas. Besides ornamentation and cadenzas, additional improvisatory practices, such as dynamics and pedalling, also required the performer to draw upon his/her own musical knowledge and creativity to fill in notational gaps where the composer left no explicit instructions. Although the present analysis will not address these practices due to space constraints, it is interesting to note how they reflect the evolution of musical notation. This contribution will investigate some of the circumstances in which the performer was called upon to improvise in order to realize the composer's intentions and complete the score, taking Beethoven's piano concertos as case studies into the changing performing practices described by Hummel and Czerny. Furthermore, it will also examine the reliability of so-called "Urtext" editions, ultimately illustrating that using these texts without considering the notational and performance practices coeval to the music can lead to historically and aesthetically incorrect interpretations. ${ }^{9}$

Compositional process and improvised embellishments The piano concerto in Beethoven's era remained connected to that of Mozart's time in its ideological approach and the practical circumstances surrounding it. For both these generations of musicians, the concerto was mainly "a personal vehicle for the composer-virtuos's performances, a means for displaying new musical ideas of which a central feature was his own distinctive

8 Carl Czerny: Vollständige theoretisch-practische Pianoforte-Schule, op.50o, Dritter Teil: Von dem Vortrage, Wien I839, p. 4 ("Ites Kapitel. Nähere Bestimmungen über die Anwendung des Forte, Piano, etc.").

9 On this topic see Christopher Hogwood: Urtext, que me veux-tu?, in: Early Music 4I/I (20I3), pp. I23-I27. 


\begin{tabular}{|c|c|c|c|}
\hline $\begin{array}{l}\text { Concertos } \\
\text { (chron. order) }\end{array}$ & $\begin{array}{c}\text { Compositional } \\
\text { Process }\end{array}$ & 1st Performance & $\begin{array}{l}\text { 1st Publication } \\
\text { (Wien) }\end{array}$ \\
\hline E-flat major WoO 4 & $\begin{array}{c}\text { Bonn, } 1784 \\
\text { (survived only piano part) }\end{array}$ & & \\
\hline $\begin{array}{l}\text { B-flat major op. } 19 \\
\text { (No. 2) }\end{array}$ & $\begin{array}{l}\text { Bonn, 1786-1792 (Sketches) } \\
\text { Wien, } 1793 \text { (Elaboration) } \\
\text { Wien, 1794-95 (Revision) } \\
\text { Prague, } 1798 \text { (Final revision) }\end{array}$ & $\begin{array}{l}\text { (?) Haydn's Academy, 19.12.1795 } \\
\text { (Wien) } \\
\rightarrow \text { Prague, October } 1798\end{array}$ & 1801, Hoffmeister \\
\hline $\begin{array}{c}\text { C major op. } 15 \\
\text { (No. 1) }\end{array}$ & $\begin{array}{l}\text { Wien: } \\
1793 \text { (Sketches) } \\
\text { March } 1795 \text { (1st elaboration) } \\
\text { Modifications: Dec. } 1795 \text { \& } \\
\text { ‘96, Oct. 1798, April 1800, } \\
\text { Dec. } 1800\end{array}$ & $\begin{array}{l}\text { (?) Hofburgtheater, 29.03.1795 } \\
\text { (Wien) } \\
\rightarrow \text { (later performances) }\end{array}$ & 1801, Mollo \\
\hline $\begin{array}{c}\text { c minor op. } 37 \\
\text { (No. 3) }\end{array}$ & $\begin{array}{l}\text { Wien: } \\
1796 \text { (Sketches) } \\
\text { April } 1800 \text { (1st autograph) } \\
\text { April } 1803 \text { (1st revision) } \\
\text { July } 1804 \text { (2nd revision) }\end{array}$ & $\begin{array}{l}\text { Theater an der Wien, 05.04.1803 } \\
\text { F. Ries concert, Wien, 18.07.1804 } \\
\text { (Beethoven conducting) }\end{array}$ & 1804, Bureau des Arts \\
\hline $\begin{array}{l}6 \text { major op. } 58 \\
\text { (No. 4) }\end{array}$ & $\begin{array}{l}\text { Wien: } \\
\text { 1803-04 (Sketches) } \\
1805 \text { (Elaboration) } \\
1806 \text { (Revision) }\end{array}$ & Theater an der Wien, 22.12.1808 $\rightarrow$ & 1808, Bureau des Arts \\
\hline $\begin{array}{l}\text { E-flat major op. } 73 \\
\text { (No. 5) }\end{array}$ & Wien, 1809 & $\begin{array}{c}\text { Wien, 20.01.1811 } \\
\text { (Archduke Rudolph, pf) }\end{array}$ & $\begin{array}{c}\text { (1810, London, } \\
\text { Clementi) } \\
\text { 1811, Leipzig, } \\
\text { Breitkopf \& Härtel }\end{array}$ \\
\hline
\end{tabular}

FIGURE I Index of Beethoven's piano concertos

style of playing"; ${ }^{\text {IO }}$ in other words, the concerto provided to musicians a means of distinguishing themselves not only as composers but also as performers in the Viennese scene. From a financial point of view, the musical soirées for which concertos were written were a reliably lucrative endeavour for composers. Thus, when Beethoven quit performing publicly in I809, his production of piano concertos ended as well.

While both Beethoven and Mozart wrote concertos with performance as a central goal, the life of a Beethoven concerto ended not on the stage but in the publishing house, a new development in the concerto tradition. This evidence will request a deeper examination.

Mozart and Beethoven are clearly separated by their usus componendi: as is evident in this summary table (Figure I), for Beethoven, performance of a concerto is not an end in itself but a forerunner to publication, and these three stages of work - compositional, performing and publishing - are strictly related. Thus, Beethoven's compositional process was both slower and more elaborate than that of Mozart. It is also notable that the several steps of the composition were directly depending from the performance 
events that sometimes were really happening, other times, to Beethoven's disappointment, never took place in the end.

During the period in which Beethoven composed his works (I784-I809), the concerto as a genre underwent a critical evolution, transitioning from Classical-style notation to the notational style that would dominate the Romantic era, a definitive change that had a particularly significant impact on the role of improvisation in this repertory. The various steps in this process are effectively reflected in Beethoven's concerto literature.

While most of Mozart's musical texts were left incomplete in one or more aspects, in the ensuing decades, composers reduced instances of incompleteness until it was ultimately eliminated from compositional practice. In Beethoven's first three piano concertos, the heritage of the Classical style is clearly evident. It is interesting what Ferdinand Ries writes about it in his Notizen:

"Ich erinnere mich nur zweier Fälle, wo Beethoven mir einige Noten sagte, die ich seiner Composition zusetzen sollte, einmal im Rondo der Sonate pathétique (Op. I3) und dann im Thema des Rondo's seines ersten Concertes in C dur, wo er mir mehrere Doppelgriffe angab, um es brillanter zu machen." II

Apart from these few additions, however, an examination of the texture of the $\mathrm{C}$ major concerto - notably in the second movement - reveals a consistent practice of writing out embellishments in the musical text (Example r).

This practice is understandable if we consider that six years elapsed between the first performance and the first printed edition, during which period Beethoven edited the text numerous times to make it increasingly complete. The first sketches date to 1793 , and Beethoven made the first elaboration between the end of I794 and early I795 in connection with a performance that took place 29 March I795, at the Burgtheater in Vienna. In this instance, Beethoven's musical text reflects one of the same limitations evident in several of Mozart's concerto scores as well: a lack of time. This is how Franz G. Wegeler remembers that occasion:

"Erst am Nachmittag des zweiten Tages vor der Aufführung seines ersten Concerts (C dur) schrieb er das Rondo und zwar unter ziemlich heftigen Kolikschmerzen, woran er häufig litt. Ich half durch kleine Mittel, so viel ich konnte. Im Vorzimmer saßen vier Copisten, denen er jedes fertige Blatt einzeln übergab. [...] Bei der ersten Probe, die am Tage darauf in Beethoven's Zimmer statt hatte, stand das Klavier für die Blasinstrumente einen halben Ton zu tief. Beethoven ließ auf der Stelle diese und so auch die übrigen, statt nach a, nach b stimmen und spielte seine Stimme aus Cis." ${ }^{12}$

11 Franz Gerhard Wegeler/Ferdinand Ries: Biographische Notizen über Ludwig van Beethoven, Koblenz I838, p. 106

12 Ibid., p.36. 

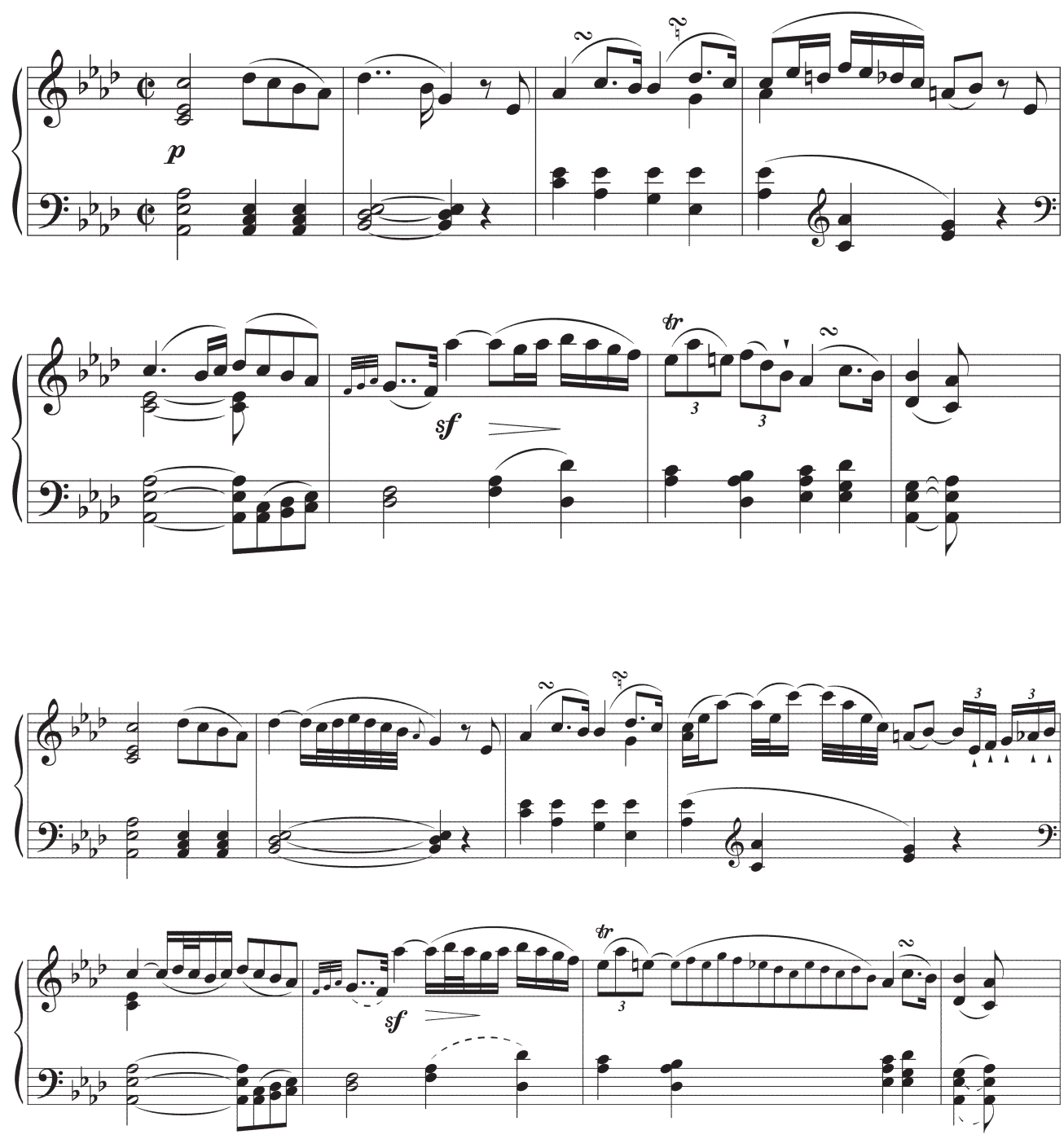

ExAM PLE 1 Ludwig van Beethoven: Piano concerto No. 1 op. 15, Largo, bb. 1-8 and 53-60

Remarkably, the description of this circumstance matches nearly perfectly Leopold Mozart's recollection of the $\mathrm{KV} 466$ premiere:

"das Concert war unvergleichlich, das Orchester vortrefflich, außer den Synfonien sang eine Sängerin vom welschen theater 2 Arien. dann war ein neues vortrefliches Clavier Concert vom Wolfgang, wo der Copist, da wir ankammen noch daran abschrieb, und dein Bruder das Rondeau noch nicht einmahl durchzuspielen Zeit hatte, weil er die Copiatur übersehen mußte." ${ }^{\text {I3 }}$

13 Letter of Leopold Mozart to Maria Anna von Berchtold zu Sonnenburg, I6 February I785 (Wien, Österreichische Nationalbibliothek), cited after https://dme.mozarteum.at/DME/briefe/letter. php?mid=I4I6, p. [2], "Lesefassung" (last consulted 4 August 20I8). On this topic see also Miucci: Mozart after Mozart. 
As was the case with many of Mozart's concertos, the piano part of Beethoven's op. I5 may not have been fully notated at this stage (I795), but the premiere took place anyway. Beethoven continued to modify op. I5 in conjunction with subsequent performance opportunities (such as December I795 and April I80o), eventually reaching a final version that he found satisfactory for publication (Mollo, I80I). Between I795-I80I, Beethoven finally had time enough to complete his piano part before it went to print.

A letter from Beethoven to Franz Anton Hoffmeister in I80I concerning the publication of the first edition of op. I9 attests to Beethoven's compositional approach, which is heavily influenced by his improvisation skills. Due to the incompleteness of the piano part, it is impossible for Beethoven to rely on professional copyists (except for the orchestral parts), for which he apologizes to his publishers:

"dabey ist es vieleicht das einzige genie-mäßige, was an mir ist, daß meine Sachen sich nicht immer in der besten Ordnung befinden, und doch niemand im stande ist als ich selbst da zu helfen, so z. B. war zu dem Konzerte in der Partitur die Klawirstimme meiner Gewohnheit nach nicht geschrieben, und ich schrieb sie jezt erst, daher sie dieselbe wegen Beschleunigung von meiner eigenen nicht gar zu leßbaren Handschrift erhalten." ${ }^{\text {I4 }}$

The publication world clearly demonstrated increased interest in the keyboard concerto among both composers and consumers: the former produced concertos in larger numbers, and this repertoire, once the near-exclusive domain of the composers themselves, now started becoming popular with other keyboardists, professional and amateur alike. Therefore, with his works being played by a wider public with varying levels of musical knowledge and ability, Beethoven, like his colleagues, recognized the necessity of more detailed notation, an evolution in his practice illustrated by the story of the c-minor Concerto op. 37 .

Beethoven started work on the concerto in 1796 , and as was the case with previous concertos (including the above-mentioned op. I9), all further elaborations of the score were related to possible performances. The final revision before the first performance came some seven years after it was begun, with the piano part still remaining very much incomplete. At the first performance, which took place at the Theater an der Wien on 5 April I803, Beethoven asked Ignaz von Seyfried to turn pages, and the latter reports that it was basically impossible to do as the piano part consisted mostly of short sketches here and there:

"beym Vortrage seiner Concert-Sätze lud er mich ein, ihm umzuwenden; aber - hilf Himmel! - das war leichter gesagt, als gethan; ich erblickte fast lauter leere Blätter; höchstens auf einer oder der anderen Seite ein paar, nur ihm zum erinnernden Leitfaden dienende, mir rein unverständliche

14 Ludwig van Beethoven: Briefwechsel. Gesamtausgabe, ed. by Sieghard Brandenburg, Vol. I: I783-1807, Munich I996, p. 72 (No. 60, 22 April I80I). 
egyptische Hieroglyphen hingekritzelt; denn er spielte beynahe die ganze Prinzipal-Stimme bloss aus dem Gedächtnisse, da ihm, wie fast gewöhnlich der Fall eintrat, die Zeit zu kurz ward, solche vollständig zu Papiere zu bringen. So gab er mir also nur jedesmal einen verstohlenen Wink, wenn er mit einer dergleichen, unsichtbaren Passage am Ende war, und meine kaum zu bergende Aengstlichkeit, diesen entscheidenden Moment ja nicht zu verabsäumen, machte ihm einen ganz köstlichen Spass, worüber er sich noch bey unserm gemeinschaftlichen, jovialen Abendbrote vor Lachen ausschütten wollte." 15

The "complete" edition of op. 37 available today owes its existence to Ferdinand Ries, who had to perform it in I804 with Beethoven conducting. Because Ries was still a student and not yet capable of improvising like the masters, Beethoven had to carefully notate the piano part. Ries himself confirms this circumstance: "Die Clavierstimme des C moll Concerts hat nie vollständig in der Partitur gestanden; Beethoven hatte sie eigens für mich in einzelnen Blättern niedergeschrieben." ${ }^{\text {I6 }}$ Ries's performance thus resulted in a score ready for publication: Beethoven had notated all the musical details necessary to make the concerto accessible to a wide range of players. ${ }^{\text {I7 }}$

This turning point in piano concerto notation is confirmed in a review in the Allgemeine musikalische Zeitung of Io April I805 that acknowledges the particular precision with which Beethoven notates texture:

"Ein solcher wahrer Virtuos kann aber auch durch dies Konzert glänzen; denn so reich es besetzt und durch alle Instrumente ausgeführt ist, so hervorstechend und dankbar ist doch die Konzertstimme. Der Komponist ist übrigens - was ebenfalls zu loben ist - allem willkührlichen Verschnörkeln dadurch zuvorgekommen, dass er, was wirklich verzieren kann, sehr genau und sorgfältig ausgeschrieben hat. Wer nur Noten spielt, dem wird dadurch zwar manche Stelle ungeheuer schwer vorkommen; aber, wie gesagt, für den ist dies Werk auch nicht."18

Beethoven's tendency to provide the performer with all necessary embellishments is confirmed in the last two concertos. The Concerto in G major op. 58 , begun in I803/04, marked the first instance in which Beethoven published the work before the first public performance: the concerto was printed by the Kunst- und Industrie-Comptoir in August I808 and was premiered at the renowned concert at the Theater an der Wien on 22 December I808. ${ }^{\text {I9 }}$ Although the edition was already circulating in Vienna, the written text

15 Ignaz von Seyfried: Recensionen, in: Cäcilia 9 (I828), p. 2I7-243, here p. 220.

16 Wegeler/Ries: Notizen, p. II5.

17 This piano concerto has been released in Vienna in the same year (1804, Bureau des Arts et d'Industrie).

18 Anon.: Recension, in: Allgemeine musikalische Zeitung 7 (I805), coll. 445-457, here col. 457.

19 Remarks of that musical evening were left by many people who attended the concert, like Ignaz Moscheles, F. Ries or I. von Seyfried; see Alexander Thayer: Thaper's life of Beethoven, rev. and ed. by Elliot Forbes, Vol.I, Princeton I99I, pp.446-451. 
scarcely resembled the version that Beethoven put forth in the concert, as is reported in Czerny's memoirs (via Nottebohm):

"so kann die mündliche Mittheilung Carl Czerny's, Beethoven habe das G-dur-Concert öffentlich sehr 'muthwillig' gespielt und bei Passagen viel mehr Noten angebracht, als da standen, eine Erklärung finden". ${ }^{20}$

This circumstance further illustrates the fact that Beethoven's approach to the piano concerto - in line with the Mozartean tradition - does not result in a text that is successfully realized through the modern attitude toward the Urtext, in which the musical text is taken as definitive and unchangeable. However, the evolutions in both Beethoven's compositional style and the concerto genre in general result in increasingly detailed musical texts, the completeness of which indeed seems to preclude any kind of addition by the performer.

Beethoven's tendency toward more detailed notation was also influenced by a factor unique to him: his deafness. By I8го, his hearing had deteriorated so much that op. 58 would be the last concerto that he would perform in public. As was mentioned above, because public performances were a good source of income for him, once Beethoven could no longer perform, he also lost interest in composing concertos. Indeed, his op. 73 concerto in E-flat major would be the last he composed and the first that he would not play himself: from that moment, Beethoven asked Ferdinand Ries or other students to play his concertos. For the premiere of op. 73, Archduke Rudolph - Beethoven's student, patron, and dedicatee of this work - was at the piano, marking a turning point in the history of this genre when a clear separation between composer and performer was definitively established. ${ }^{2 I}$

For this occurrence, the composer provided not only all the embellishment but also the cadenza, marking the first instance in which a cadenza was structurally incorporated into the score. With op. 73, Beethoven also adopted a much shorter and more linear compositional process: given that there would be no occasions on which the composer himself would perform the piece, he worked on it only in I809/Io, taking no significant further steps till the performance and publication.

Thus, in terms of the degree of completeness of the piano texture, if Beethoven's early output appears linked to the Classical model and attitudes (particularly the expectation for improvisation by the performer), the second half of his output looks toward

Gustav Nottebohm: Zweite Beethoveniana, Leipzig 1887, p. 75. On this topic see Barry Cooper: Beethoven's revisions to his Fourth Piano Concerto, in: Performing Beethoven, ed. by Robin Stowell, Cambridge I994, pp. 23-48.

21 The concert took place at the Palais Lobkowitz on the evening of I3 January I8II; see Rita Steblin: Beethoven in the Diaries ofJohann Nepomuk Chotek, Bonn 20I3, Pp. Ir3f. 
the new Romantic ideas and performance practices. This change certainly stemmed in part from several personal factors: his increasing deafness, his inability to continue performing in public, and the subsequent obligation to entrust other performers with his works. In looking at the historical context, however, one must acknowledge the influence of the most significant revolution in musical life between the $18^{\text {th }}$ and $19^{\text {th }}$ century: the rise of the middle classes. This sociological phenomenon created a wider and ever-increasing consumer base in the musical world: more people sought piano instruction, though most of the new practitioners lacked the skills necessary to perform difficult concertos (let alone improvise).

Thus, given the evolution of both piano technique and aesthetics and the demographic changes among pianists, composers felt compelled to fix all necessary information in the score, which in turn reduced the space allotted for performer improvisation. This new notational practice both asserted the composer's ultimate authority over the composition and made the works accessible to performers of varying degrees of ability.

Beethoven's newly adopted practice of clearly and fully notating embellishments in op. 73 aligns with a passage in Hummel's Anweisung (r828) in which he describes the shift away from performer-initiated embellishment to composer-controlled embellishment:

"Ausschmückungen, Vor-, Nachschläge, und andere Manieren sind in der Musik wegen genauerer Verbindung der Töne, des Zusammenhangs der Melodie, des Nachdrucks, und des guten und schönen Vortrags unentbehrlich; doch, da die frühere grosse Anzahl solcher Zeichen, und ihr oft sehr geringer Unterschied, viele derselben den Schüler vernachlässigen liess, in der neuen Schreibart aber mehr ganz unnöthig wurden, und andere dem Spieler, zur Gewissheit des gewünschten Vortrags, durch Noten vorgezeichnet werden: so scheint mir eine Einschränkung derselben theils nöthig, theils rathsam." 22

Cadenzas and Eingänge The attitude toward the performance of cadenzas and Eingänge (lead-ins) followed the same direction, both in Beethoven's practice and in general. His Emperor Concerto marks a turning point; he writes in the score of the first edition: "Non

See Hummel: Anweisung, p. 393. Actually the difference in the embellishment practice of his own days, in spite of that of the Classical era, was that significant that Hummel suggests further, in a footnote on the same page: "Will Jemand auch die früher üblich gewesenen Zeichen, wegen des Vortrags der damaligen Komposizionen, kennen lernen, so findet er in ältern Lehrbüchern hinlängliche Erläuterung." Indeed, Hummel did not treat this issue only on a theoretical level: recognizing the complexity of this repertory concerning embellishments - and cadenzas as well -, and knowing how many early i $9^{\text {th }}$ century amateur pianists were unprepared to improvise, he was one of several composers who proposed arrangements of these concertos that "included] Cadences and Ornaments, expressly written." On this topic see Miucci: Mozart after Mozart, and the prefaces to the critical editions of some of these arrangements published in Launton (нн edition): KV 466 (2013), KV 456 (20I4), KV5O3 (20I5) and KV 49I (20I7). 


\begin{tabular}{|c|c|c|c|}
\hline $\begin{array}{l}\text { Concertos } \\
\text { (chron. order) }\end{array}$ & 1st movt & 2nd movt & 3rd movt \\
\hline E-flat major WoO 4 & ad libitum & ad libitum & \\
\hline $\begin{array}{l}\text { B-flat major op. } 19 \\
\text { (No. 2) }\end{array}$ & ad libitum & (hidden obbligato) & \\
\hline $\begin{array}{l}\text { Cmajor op. } 15 \\
\text { (No. 1) }\end{array}$ & ad libitum & & (Eingang obbligato) \\
\hline $\begin{array}{c}\text { c minor op. } 37 \\
\text { (No. 3) }\end{array}$ & ad libitum & (pre-tutti obbligato) & \\
\hline $\begin{array}{l}6 \text { major op. } 58 \\
\text { (No. 4) }\end{array}$ & ad libitum & (pre-tutti obbligato) & ad libitum \\
\hline $\begin{array}{l}\text { E-flat major op. } 73 \\
\text { (No. 5) }\end{array}$ & obbligato & & \\
\hline
\end{tabular}

FIGURE 2 Index of Beethoven's piano concerto cadenzas

si fa una cadenza, ma s'attacca subito il seguente", requesting that the performer uses the given cadenza and refrain from supplying his or her own.

The earlier concertos, performed by the composer himself, were published in the Classical tradition without a cadenza included in the piano part and with the place for the cadenza marked ad libitum in several outer movements (Figure 2).

Beethoven did compose cadenzas and Eingänge for these concertos that are used in many present-day performances; however, these were written much later in his career: the paper used suggests a date between 1808 and I809. Furthermore, they fit the compass of a six-octave piano, which he used only after the concertos were released. These cadenzas were published posthumously in I864, neither in accordance with any stated wish of Beethoven nor under his supervision, and it is difficult to know if they are stylistically similar to those the composer himself used in performance.

Considering the significant number of sources jointly addressing Mozart and Beethoven as ultimate masters in free improvisation, and given how delighted Beethoven was to undertake this challenge in performance, it is highly doubtful that Beethoven would have used these composed cadenzas. Additionally, if these exempla were intended for public performance, it is unclear why there is no evidence that Beethoven ever attempted to have them published. A review in the Berliner Allgemeine musikalische Zeitung (I826) acknowledges this doubt:

"Bitte an Beethoven.

Möchte es doch dem Meister Beethoven gefallen, zu seinen Pianofortekonzerten Kadenzen zu schreiben. 
Ein Stein des Anstoßes, warum die Beethoven'schen Konzerte so selten von den Pianofortvirtuosen vorgetragen werden, liegt sicher mit darin: daß es nicht Jedermanns Sache ist, eine Kadenz zu schaffen, die sich mit der Beethoven'schen Muse verträgt. Außerdem hat es aber dem Schreiber dieses auch immer scheinen wollen, wenn er Beethovensche Konzerte mit ipse fecit - Kadenzen vortragen hörte, oder (unter vier Augen gesagt, Herr Redakteur!) selbst spielte, als trüge man ein sammtnes Festkleid mit kattunenen Läppchen."23

This excerpt reveals two important things: I) that it was very difficult to match Beethoven's style, especially concerning cadenzas; and 2) that until I826, there were no authorized cadenzas on the market, and it is unclear the extent to which the manuscript cadenzas (on which current published versions are based) were disseminated, if at all. For whom, or for what occasion, did Beethoven compose these examples?

The manuscript material in question consists of 17 cadenzas and lead-ins for the concertos from op. I5 to op. 58 , including those for the piano arrangement of op. $6 \mathrm{I}$ and for the Mozart Piano Concerto in $d$ minor KV $466 .{ }^{24}$

It is reasonably certain that the second piece in this set, a cadenza for the first movement of op. $15,{ }^{25}$ was a private commission. According to Kinsky/Halm, ${ }^{26}$ this was the cadenza that Beethoven had to compose for a "Liebhaber" concert which took place in Vienna on 3I January I808. ${ }^{27}$ There is correspondence, dated 30 January, between Beethoven and Count Moritz von Dietrichstein concerning the possibility that Johann Baptist Steiner von Felsburg (I756-I832), ${ }^{28}$ a dilettante pianist, would play op. I5 on 3I January; Beethoven suggests:

"Ich rathe ihnen - den H.[errn] Felsenburg nicht spielen zu lassen, gestern hielt ich für Schüchternheit, was ich heute für Ungeschicklichkeit erkläre - die Cadenz habe ich geschrieben - aber geben sie acht, Er fällt, Eh er zur Cadenz kömmt - machen sie lieber 2 simphonien - ich habe dem H. Felsenburg selbst gesagt, dass ich ihm es nicht rathe Morgen zu spielen - Es giebt eine wahre schweinerei. NB. sobald er das Konzert besser kann, kann er es spielen." ${ }^{29}$

23 C. K-s.: Bitte an Beethoven, in: Berliner Allgemeine musikalische Zeitung 3 (1826), p. 220.

24 See the Beethoven Complete Edition: Beethoven Werke, section viI, Vol. 7, ed. by Joseph SchmidtGörg, Munich/Duisburg I967, whose critical report has been recently published (Munich 20II) by Friedhelm Loesti.

25 Beethoven-Haus Bonn, Sammlung H. C. Bodmer, нсв Mh го.

26 Beethoven. Thematisch-bibliographisches Werkverzeichnis, ed. by Kurt Dorfmüller, Norbert Gertsch and Julia Ronge, Munich 20I4, p. 83.

27 See Otto Biba: Beethoven und die "Liebhaber Concerte" in Wien im Winter I807/I808, in: Beiträge '76-78. Beethoven Colloquium I977, ed. by Rudolf Klein, Kassel I978, p. 85 .

28 J.B. Steiner von Felsburg was the Court Secretary at the Chancellor's Office and, according to Hanslick, distinguished himself in the interpretation of Beethoven's music; see Eduard Hanslick: Geschichte des Concertwesens in Wien, Wien I869, p. 214.

29 Ludwig van Beethoven: Briefwechsel. Gesamtausgabe, Vol. 2: I808-I8I3, p. 5 . 
On the occasion of this private amateur concert, Beethoven showed very little trust in this dilettante that he suggested replacing the concerto with another symphony. Nevertheless, Beethoven composed a cadenza, of which, unfortunately, only the first 58 bars survive. The cadenza was likely mutually beneficial: Beethoven did not have to risk relying on Felsburg's improvisational skills, and presumably the latter, being an amateur, would have required, or at least appreciated, a written cadenza anyway.

Thus, it is very interesting that Beethoven adopted a completely different attitude in a remarkably similar circumstance, according to a report by Ferdinand Ries:

"Beethoven hatte mir sein schönes Conzert in C moll (Opus 37,) noch als Manuscript gegeben, um damit zum ersten Male öffentlich als sein Schüler aufzutreten; auch bin ich der Einzige, der zu Beethoven's Lebzeiten je als solcher auftrat. [...] Beethoven selbst dirigirte und drehte nur um und vielleicht wurde nie ein Concert schöner begleitet. Wir hielten zwei große Proben. Ich hatte Beethoven gebeten, mir eine Cadenz zu componieren, welches er abschlug und mich anwies, selbst eine zu machen, er wolle sie corrigiren. Beethoven war mit meiner Composition sehr zufrieden und änderte wenig; nur war eine äußerst brillante und sehr schwierige Passage darin, die ihm zwar gefiel, zugleich aber zu gewagt schien, weshalb er mir auftrug, eine andere zu setzen. Acht Tage vor der Aufführung wollte er die Cadenz wieder hören. Ich spielte sie und verfehlte die Passage; er hieß mich noch einmal, und zwar etwas unwillig, sie ändern. Ich that es, allein die neue befriedigte mich nicht; ich studirte also die andere auch tüchtig, ohne ihrer jedoch ganz sicher werden zu können. - Bei der Cadenz im öffentlichen Concerte setzte sich Beethoven ruhig hin. Ich konnte es nicht über mich gewinnen, die leichtere zu wählen; als ich nun die schwerere keck anfing, machte Beethoven einen gewaltigen Ruck mit dem Stuhle; sie gelang indessen ganz und Beethoven war so erfreut, daß er laut: bravo! schrie. Dies electrisirte das ganze Publikum und gab mir gleich eine Stellung unter den Künstlern. Nachher, als er mir seine Zufriedenheit darüber äußerte, sagte er zugleich: 'Eigensinnig sind Sie aber doch! Hätten Sie die Passage verfehlt, so würde ich Ihnen nie eine Lection mehr gegeben haben.'”30

From Ries's recollection we learn firstly that his cadenza was not in fact a free, extemporaneous inspiration but the final result of a complex compositional process. At the time that this concert took place - July I804 - Ries was only twenty years old and had been studying with Beethoven for only a very brief period; thus, it was understandable that, instead of improvising a cadenza, he would attempt to compose one under Beethoven's supervision. Beethoven himself adopted a similar approach, producing Skizzen for cadenzas that were likely to be used for specific performances, such as the sketch for the B-flat major Concerto op. I9, which he wrote at age 24, a sparser sketch than Ries's efforts exemplifying Beethoven's genius for improvisation. ${ }^{3 \mathrm{I}}$

There is additional evidence that Beethoven's approach to cadenzas was based on balancing free, spontaneous improvisation with a pre-prepared structure. In a sketch for

Wegeler/Ries: Biographische Notizen, pp. $1 \mathrm{f}^{\mathrm{f}} \mathrm{f}$

Paris, Bibliothèque nationale de France, département Musique, Ms-7o (http://gallica.bnf.fr/ark:/ I2I48/btvib550025Iop). 
the song Sehnsucht WoO I34, Beethoven left written indications concerning improvisation; on leaf 3 r, he specifies: "Man fantasirt eigentlich nur, wenn man gar nicht acht giebt, was man spielt, so - würde man auch am besten, wahrsten fantasiren öffentlich - sich ungezwungen überlassen, eben was einem einfällt." ${ }^{2}$ Beethoven's attitude appears to be in strict continuity - down to the very words he uses - with Mozart's: the latter, referring to an Eingang in his piano concerto KV 27I, stated: "wenn ich dieses Concert spielle, so mache ich allzeit was mir einfällt". 33 Nevertheless, Beethoven actually appears to base this inspiration of the moment on a planned structure: on the same sketch of $\mathrm{WoO}_{134}$, on leaf $3 v$, it reads: "Lied variirt am Ende Fuge und mit pianissimo aufgehört auf diese Art jede Fantasie entworfen und hernach im Theater ausgeführt."

The second notable element in Ries's testimony is Beethoven's entirely different attitude toward the possibility of someone other than himself playing cadenzas in his piano concertos. In this case, unlike that concerning Felsburg, Beethoven seems to encourage Ries to produce his own cadenza (with some supervision, of course), trusting that Ries's pedagogical path would ultimately lead to him becoming a professional musician capable of improvising. In other words, we see Beethoven's double attitude: one for the Liebhaber who needs precise instructions and musical text from the composer for a cadenza, and one for the Kenner who is sufficiently skilled in improvising to produce his own cadenza.

This context must be properly considered in discussing the evidence surrounding the autographs of Beethoven's cadenzas. Recent studies have hypothesized that these autographs were intended for Archduke Rudolph,34 who was undoubtedly a talented keyboardist but nevertheless still an amateur. It is likely, therefore, that these cadenzas and Eingänge represent not Beethoven's personal improvisational style but rather his pedagogical approach: these pieces may have been specially designed to assist Rudolph's musical development or to compensate for his weaknesses. Thus, these autographs may not provide reliable insight into Beethoven's personal improvisational practice.

Rudolph's ownership of these manuscripts is proven through the appearance of the archduke's library cataloguing number on the first sheet of each cadenza; this evidence in itself is insufficient for proving that the pieces were originally conceived for him. However, there are other elements that support this theory. Given his love of Beethoven's

Beethoven-Haus Bonn, Sammlung H. C. Bodmer, НСв Mh75.

33 Mozart. Briefe und Aufzeichnungen I780-I786, ed. by Wilhalm A. Bauer and Otto Erich Deutsch, Kassel I963 (Briefe und Aufzeichnungen, Gesamtausgabe, Vol.3), p. 25r; see Miucci: Mozart after Mozart. 
works, Rudolph is a likely candidate for the hypothetical commission of these cadenzas; in fact, he is the dedicatee of the last two piano concertos opp. 58 and 73 . One might further speculate that Rudolph acquired these manuscripts not only for inclusion in his music library but as a solution for his private performances, much like Felsburg, who received a cadenza from Beethoven in I808. This supposition is supported by the fact that Archduke Rudolph was the performer for the premiere of op. 73, as mentioned above. 35

Furthermore, the end of the first decade of the $19^{\text {th }}$ century was a period in which Rudolph had a marked interest in Beethoven's concerto repertory, and the composer's authorship of these manuscripts was likely inspired by several performances that took place in this same time. The compass of the cadenzas for opp. I5 and I9 and those for Mozart's Kv 466, for example, reaches six and a half octaves, indicating that these were intended for the size of instrument that had become popular early in the century.

The year I809 also marked a period of transition in Beethoven's keyboard notation toward a higher degree of completeness, as the above examination of op. 73 demonstrated. These cadenzas and lead-ins could result from this new trend, but the evidence of pedagogical intent strengthens their connection to Rudolph; further analysis of the material is needed to ascertain both Beethoven's purpose in writing these cadenzas and what insight the manuscripts provide into his improvisation and/or pedagogy.

It is useful to briefly summarize the contents of the manuscript cadenzas: except for cadenza No. 2, which was written for Felsburg, the collection provides one cadenza and occasionally Eingänge for concertos requiring ad libitum contributions from the performer; for opp. I5/I and 58/I-III, Beethoven provides multiple cadenzas and Eingänge. With respect to these concertos, it appears that Beethoven does not provide multiple possibilities for use in specific performances (id est improvisations that differ in material and structure but are similar in technical and musical demands), but he is rather providing improvisations of varying difficulties, possibly for Rudolph to use as his level improves. For instance, a striking difference between the examples for op. $15 / \mathrm{I}$ is the length: ${ }^{6}{ }^{6}$ while the first one consists of 32 bars, the alternative version numbers 126 bars. The harmonic structures of the two cadenzas differ as well: the first cadenza appears to be more stable, remaining principally in the dominant (except for a brief modulation to E-flat major in the middle) as would be expected in the Classical tradition; in contrast, the second cadenza is characterized by persistent harmonic instability and reaches tonalities even more distant than E-flat (D-flat major and c-sharp minor, for example). This tendency toward an expanded harmonic environment was a hallmark of Beethoven's free improvisational style in general and of his piano concertos; this was one of the ways in which Beethoven 
broke with Classical tradition, in which distant modulations in cadenzas were viewed with scepticism. 37

In addition to the differences in dimension and harmonic material, the complexity of the piano texture reveals a definitively different approach in these two cadenzas. The first cadenza is constructed with basic scales and arpeggios while the second contains considerably more demanding figurations such as double thirds, octaves, double trills, et cetera.

This gradual approach may reflect Beethoven's awareness that he was addressing an amateur rather than a professional pianist, someone who required a ready-made solution for a performance due to lack of practice time or poor improvisational skills. Again, this general picture might lead back to Archduke Rudolph.

The final reason why these cadenzas might have been a special commission is the graphic layout. These autographs are unusually clear and legible, which might suggest that these manuscripts are not rough sketches but rather clean copies. This in turn raises the question as to why Beethoven would not have delegated such an ostensibly mundane task to one of his copyists, suggesting that perhaps these cadenzas were a special offering, if not a present, and that it should be in Beethoven's own hand was thus important. Again, given that these manuscripts align with the compositional time frame of the concertos opp. 58 and 73 , all signs point to Rudolph. ${ }^{8}$ The clarity of the autographs, in conjunction with the apparent lack of intent on Beethoven's part to publish these, indeed suggests that these might have been a gift, probably for his patron, who, according to contemporary

37 Even in the third example of the cadenza for op. I5/i - the one for Felsburg (нсв Mh го) - one finds, at least in the portion which survived, the same harmonic instability with modulations to E-flat major, f minor or g minor. Actually, the change in style introduced by Beethoven was already foreseen by Daniel Gottlob Türk in I789. In his Klavierschule, describing the composition of a cadenza, he firstly states: "Ausweichungen in andere, besonders sehr entfernte, Töne finden entweder gar nicht statt z.B. in kurzen Kadenzen, oder sie müssen mit vieler Einsicht, und gleichsam nur im Vorbeygehen, angebracht werden. Auf keinen Fall sollte man in Töne ausweichen, worein der Komponist in dem Tonstücke selbst nicht ausgewichen ist." Immediately after, Türk moderates his view: "Ursprünglich lag bey den Kadenzen blos die Harmonie des Quartsextenakkordes und allenfalls des darauf folgenden Dreyklanges zum Grunde; allein gegenwärtig möchte dieser harmonische Bezirk wohl zu enge seyn. Man kann daher ausweichen; nur verweile man in Nebentönen \&c. nicht zu lange, damit nicht das Gefühl des Haupttones verlösche." Türk: Klavierschule, oder Anweisung zum Klavierspielen für Lehrer und Lernende, Leipzig/ Halle I789, p.3Ir.

38 On this account it should be also considered that "from 1809 to the end of his life Beethoven remained financially dependent on the Archduke's largesse, all the more so when Lobkowitz went bankrupt in I8II and Kinsky died in I8I2". See Lewis Lockwood: Beethoven as Sir Davison. Another Look at his Relationship to the Archduke Rudolph, in: Bonner Beethoven-Studien, ed. by Bernhard R. Appel, Joanna Cobb Biermann and Julia Ronge, Bonn 2014, pp. I33-I40, here p. I35. 
accounts, was an extremely diligent student but still belonged to the category of Liebhaber, incapable of improvising like the masters.

Through tracing the history of these cadenzas, it becomes evident that it is risky to consider them as the only possibilities for use in performance, as has become the established practice in $20^{\text {th }}$-century philological and performance traditions.

At the end of this historical recollection it is possible to propose some concluding observations. It is clear that Mozart and Beethoven shared similar attitudes toward the concerto, the role of the performer, and the properties of the musical text. However, the significant changes between the I78os - Mozart's most productive decade - and the early I $9^{\text {th }}$ century inspired an evolution in the concerto genre. The rise of the middle class and the resultant increase in performers, the growing network of music publishers and the increasing number of consumers, and the spread of music-making and concert-going as leisure activities all impacted composers' approaches to the concerto. From these changes arose a separation between performer and composer; until Beethoven's days, these had been one and the same. It is understandable, therefore, that the expectations and opportunities for improvisation in concerto performance were gradually reduced during this evolution which resulted not only from a shift in aesthetics but from the influence of the burgeoning ranks of amateur musicians.

Thus, contemporary editorial practices concerning Urtexts, along with the often exaggerated Werktreue adopted by contemporary performers, may be the least beneficial approach to this much-loved repertoire. To address Beethoven concertos without carefully considering how the works were interpreted in their time and the role that improvisation played is to adopt the attitude of the $\mathrm{I}^{\text {th-century amateurs, who gratefully }}$ accepted a pre-prepared solution to improvisation that in many ways forsook a practice that was once at the very core of these works. As the continuity in the textural issues existing between the Mozart and Beethoven repertories shows, it's very risky, both from a historical and an aesthetic point of view, to entrust univocally on our heritage after the early printed edition of Classical style piano concertos: as evidence shows, it is impossible in this literature to split the philological and critical process from the performance practice, as it is not possible to split the performing process from compositional one. 


\section{Inhalt}

Vorwort 7

Maria Grazia Sità Improvisation and the Rhetoric of Beginning

Lutz Felbick Der Compositor extemporaneus Beethoven als »Enkelschüler« Johann Sebastian Bachs 34

Giorgio Sanguinetti A Partimento in Classical Sonata Form by Giacomo Tritto 57

Michael Lehner »Und nun sehe man, was hieraus gemacht werden kann«. Carl Czernys Anleitung zum Fantasieren als implizite Harmonie- und Formenlehre 69

Leonardo Miucci Completing the Score.

Beethoven and the Viennese Piano Concerto Tradition $\quad 9^{8}$

Martin Skamletz Joseph Preindls Klavierfantasien als Echo von Opern- und Oratorienaufführungen in Wien um I800 II6

Martin Skamletz »Classisches Clavierspiel«. Joseph Lipavsky und das Rondeau-Fantaisie $\quad$ I37

Sonja Wagenbichler Showdown am Klavier. Zur Kultur pianistischer Wettstreite im Wien des I8. und I9. Jahrhunderts $\quad$ I64

Stephan Zirwes Formale Dispositionen in den komponierten Fantasien zur Zeit Beethovens I75

Nathalie Meidhof Variation, »Harmoniekenntniss« und Improvisation. Beethovens Fünf Variationen über das englische Volkslied »Rule Britannia« für Klavier in D-Dur (WoO 79) I92

Namen-, Werk- und Ortsregister 202

Die Autorinnen und Autoren der Beiträge $\quad 208$ 


\section{DAS FLÜCHTIGE WERK}

Pianistische Improvisation der Beethoven-Zeit •

Herausgegeben von Michael Lehner, Nathalie Meidhof

und Leonardo Miucci unter redaktioneller

Mitarbeit von Daniel Allenbach 


\section{MUSIKFORSCHUNG DER \\ Hochschule Der KÜnste Bern \\ Herausgegeben von Martin Skamletz \\ und Thomas Gartmann}

Band 12 
0 Dieses Buch ist in gedruckter Form im Juli 20I9 in erster Auflage in der Edition Argus in Schliengen/Markgräflerland erschienen. Gestaltet und gesetzt wurde es im Verlag aus der Seria und der SeriaSans, die von Martin Majoor im Jahre 2000 gezeichnet wurden. Gedruckt wurde es auf Eos, einem holzfreien, säurefreien, chlorfreien und alterungsbeständigen Werkdruckpapier der Papierfabrik Salzer im niederösterreichischen Sankt Pölten. Das Vorsatzpapier Caribic cherry wurde von Igepa in Hamburg geliefert. Rives Tradition, ein Recyclingpapier mit leichter Filznarbung, das für den Bezug des Umschlags verwendet wurde, stellt die Papierfabrik Arjo Wiggins in Issyles-Moulineaux bei Paris her. Das Kapitalband mit rot-schwarzer Raupe lieferte die Firma Dr. Günther Kast aus Sonthofen im Oberallgäu, die auf technische Gewebe und Spezialfasererzeugnisse spezialisiert ist. Gedruckt und gebunden wurde das Buch von der Firma Bookstation im bayerischen Anzing. Im Internet finden Sie Informationen über das gesamte Verlagsprogramm unter www.editionargus.de, zum Institut Interpretation der Hochschule der Künste Bern unter www.hkb.bfh.ch/interpretation und www.hkb-interpretation.ch. Die Deutsche Nationalbibliothek verzeichnet diese Publikation in der Deutschen Nationalbibliografie; detaillierte bibliografische Daten sind im Internet über www.dnb.de abrufbar. (C) der zeitgleich erschienenen digitalen Version: die Autorinnen und Autoren, 2019. Dieses Werk ist lizenziert unter einer Creative Commons Namensnennung-Nicht kommerziell 4.0 International Lizenz (CC BY-NC 4.0). Dor: https://doi.org/I0.26045/kp64-6I76 ISBN 978-3-93I264-92-5 